\title{
Fascination of the Abomination in Joseph Conrad's Heart of Darkness
}

\author{
A. Hariharasudan, R. Juki Javla, S. Robert Gnanamony
}

\begin{abstract}
This research paper makes an attempt to go into the heart of Kurtz, the lead character in Joseph Conrad's novella Heart of Darkness and to see how the heart of this European settler and pioneer goes into Congo in order to search for ivory and how he traumatises the native population into just pawns in his diverse manoeuvres. As a result of his overweening ambition, Kurtz has to pay a very heavy fine just as his predecessor in Europe Dr. Faustus pays with his soul. They are cousins of the same blood and their hearts are overflowing with darkness.
\end{abstract}

Keywords: Abomination, Terror, Wilderness, Darkness, Expedition, Raided country, shamefully abandoned.

\section{INTRODUCTION}

From the very inception of the world, man has taken a great fascination for Abomination. Even in the Bible, many a time the rulers of Israel have taken a fancy for Abomination, Abominable creature. In I Kings chapter II, King Solomon the wisest man on Earth at that time and also well-favoured by God went the after the Goddess of the Zidonians, Ashtoreth and also went after Milcom, "The Abomination of the Ammonites" [1]. In the Garden of Aden itself, Adam and Eve, more than Adam, Eve took a fancy for the Abominable creature the Serpent. She allowed herself to be seduced by the Serpent. Let us see. What Milton says about it: "The Serpent Subtlest Beast of all the Field" [2] entered surreptitiously into the Garden of Aden and tempted Eve to eat forbidden fruit standing tall in front of Eve the Serpent's [. . .] gentle dumb expression turned at length The Eye of Eve to mark his pray; he glad Of her attention gained, with Serpent Tongue Organic, or impulse of vocal Air, His fraudulent temptation [2].

Falling victim to the most abominable creature, the mother of humankind passes way for all kinds of ugliness and sin. In Conrad's text "Heart of Darkness" Kurtz, the villain partakes all kinds of ugliness and projects himself as the most dreaded villain.

Kurtz, the white European has positioned himself in the Jungles of Congo and has been creating terror in the black Congo natives. He has just one ambition in his life and career. It is to get Ivory. He will do anything to get it like Dr. Faustus in Christopher Marlow's play. He will struggle with the power of Darkness to get ivory. He will even, like Dr. Faustus bargain "His soul with the devil" [3]. He will destroy

Revised Manuscript Received on December 24, 2019

* Correspondence Author

Dr. A. Hariharasudan*, Department of English, Kalasalingam Academy of Research and Education, Krishnankoil, Tamil Nadu, India. Email dr.a.hariharasudhan@gmail.com

R. Juki Javala, Department of English, Kalasalingam Academy of Research and Education, Krishnankoil, Tamil Nadu, India. Email: abijuki18137@gmail.com

Dr. S. Robert Gnanamony, Department of English, Kalasalingam Academy of Research and Education, Krishnankoil, Tamil Nadu, India. anyone that comes in his way. He would not mind destroying the entire Jungle. He will, "Exterminate all brutes!" [3]. Quite often he is heard to say, 'My Intended' [3] he is the lord of the Jungle. As Joseph Conrad says,

The wilderness had patted him on the head, and behold, it was like a ball-an Ivory ball; it had caressed him, and-Lo!-he had withered; it had taken him, Loved him, embraced him, got into his veins, consumed his flesh, and sealed [...][3].

Kurtz is extremely ambitious like any dictator of the world, and he wants to possess everything that his eye sees. He thinks that everything belongs to him, but at the same time, he is oblivious of the fact that "many powers of darkness claimed him for their own" [3]. He is a cruel destroyer of flora and fauna of the Congo Jungle. He has exterminated quite a good number of the mighty Pachyderm species to possess their ivory. With the lofty tone, he would exclaim "My Intended, my ivory, my station, my river, my_everything belonged to him" [3] like Julius Ceasar who after winning a war against Pharnaces II of Pontus at the Battle, proclaimed aloud, "I came, I saw, I conquered", Kurtz' valiant style is nothing short of Julius Ceasar's or for that matter Alexander the Great's. He has "taken a high seat amongst the devils of the land" [3].

Kurtz is a powerful speaker. He has commanded love and respects from the natives and also the Whites alike at the same time he has also incurred the wrath of many. His acts have been abominable, but the native's chiefs adore him. Like the dedicator of Enver Pasha of Turkey who ruled over turkey from 1913 to 1918 who committed genocide of Armenians of an about 2.5 million, god alone knows how many blacks and elephants Kurtz would have killed.

Kurtz is the first class agent, and he is now an in-charge of a trading post. It is a significant one, "in the true_country, Sends in as much ivory as all the others put together..." [3]. In the beginning, Kurtz was an ordinary trader from his youth onwards he has been employed in the Congo region. $\mathrm{He}$ is obeyed. He inspires neither love nor fear. However, he inspires "uneasiness", "Just uneasiness-nothing more" [3]. $\mathrm{He}$ is neither a genius nor a intelligent for organising. His position has come to him because he has never fallen ill, he is very healthy, "a kind of power in itself" [3]. Once different tropical illnesses infected and killed almost all foreign agents in that station, but he was spared. Somebody heard him say "Men who come out here should have no entrails" [3] the whole region where Kurtz lives, the world 'ivory' rings in the air it is whispered: "like a whiff from some corpse" [3] on all accounts Kurtz must be obeyed. The brick maker says to Marlow, "Serve him right. Transgression-Punishment-bang! Pitiless, pitiless. That is the only way" [3]. 
Several black slaves guard him with their staves in their hands the black servant who guards Marlow is also hits with the lance by the orders of Kurtz. Later the black dies in the lap of Marlow.

Kurtz neither fears God nor devil. No man can be a threat to him those who are around him praise him; to the skies, "Mr. Kurtz was a "universal genius"” [3]. He has gathered exchanged cheated or taken more ivory when compared to all the other agents together. He is a "gifted creature" [3] he has a power of words. His vocabulary is amazing. His tone is captivating. Like Lucifer in the Garden of Eden who speaks enticing expression before Eve, would penetrate any fortified heart. The Russian personal assistant of Kurtz bears testimony to this. Hear his words,

The one that stood out pre-eminently, that carried with it a sense of real presence, was his ability to talk, his words the gift of expression, the bewildering, the illuminating, the most exalted and the most contemptible, the pulsating stream of light, or the deceitful flow from the heart of an impenetrable darkness [3].

Kurtz has wholly integrated himself with the local black customs and culture. He would "preside at certain midnight dances ending with unspeakable rites" [3] he would appear before the natives (savages) as a supernatural being. Some would even consider him a deity. To quote the Russian again, "whatever he was, he was not common. He had the power to charm or frightened rudimentary souls into an aggravated witch-dance in his honour" [3].

Just us Mark Antony encountered tough times in one of his expedition, Kurtz had to undergo a similar experience when he came to the Congo region for the first time. He was then a youth.

[...] For month- for years- his life had not been worth a day's purchase; and there he was gallantly, thoughtlessly alive, to all appearance indestructible solely by the virtue of his few year and his unreflecting audacity [3].

When Mark Antony went to Modena to contain rebellion there, he killed Hirtius and Pansa. However, he was caught up with his army in a severe famine. Even though

Antony was delicately brought up; he very graciously endured the famine with great fortitude. He even drank the urine of horses and ate the roughest berries; he also fed on the bark of trees. [...] [4].

Even though Kurtz has been one of the two important characters in the Novel, we went to him much later. Joseph Conrad built up his image step by step with reports collected from those who have known him well. From the Russian's account Kurtz we come to know that Kurtz has been a paradox because "His very existence was improbable, inexplicable, and altogether bewildering. He was an insoluble problem. It was inconceivable how he had existed, how he had existed, how; he had succeeded in getting so far, how he had managed to remain"[3] from the Russian, we again understand that Kurtz has been so persistent in his vision of getting tons of ivory. In this effort, he would go hungry; he would become lonely; he would make futile wanderings for months and years. His deep-seated Glamour would never leave him. As a Russian says,

Glamour urged him on; glamour kept him unscathed. He surely wanted nothing from the

wilderness but space to breathe in and to push on through [3].

The Russian has nursed Kurtz through illnesses sickness of any kind would not deter him in any way from wandering alone in the depths of the forest nobody else would dare do it. Quite obviously, he has been exploring the deep forest. He has discovered a lot of villagers and a lake too. Most of his expectation has been for ivory. In fact, "he raided the country" [3] he has known the art of getting then natives' support. As the Russian testifies, "They adored him" [3] to the natives of Congo, "He came to them with thunder and lightning...... and they had never seen anything like it-and very terrible. He could be very terrible" [3]. He even pointed his Gun at the Russian once for keeping some ivory away from him. The Russian tells Marlow, "He stated he would fire me unless I offered him the ivory and then go out of the country, because he could do so, and had a fancy for it, and there was nothing on earth to stop him from killing whom he jolly well pleased" [3] for many months Kurtz would disappear. He would go and live with the natives like one of them. He has embedded their culture. He is adored he would appear unpredictably "with the intention to all appearance of making a raid either across the river or downstream. Evidently the appetite for more ivory had got the better of the....less material aspirations" [3] Marlow makes the pronouncements, "Oh, he is bad, very bad" [3] Kurtz has "ruined the district" [3] he has lacked "restraint in the gratification of his various Lusts" [3]. Kurtz's unrestraint hunt does not go for long. His organised distraction of the jungle would make a boomerang effect on him. The Russian adds, "But the wilderness had found him out early and had taken on him a terrible vengeance for the fantastic invasion" [3] like T.S. Eliot's The Hollow Man, Kurtz "was hollow at the core" [3]. Kurtz was not at all afraid of the Natives. They would not stir until he gives them command as he extraordinary. "The camps of these people surrounded the place, and the chiefs came every day to see him. They would crawl...." [3] it has been a practice of Kurtz to kill the rebels and cut their heads off. Unfortunately, Kurtz has to die a tragic death. The camp has no medicine and no good food. The Russian continues, "he was shamefully abandoned" [3].

Marlow sees the terribly sick Kurtz being carried in a stretcher by some savages followed by streams of human beings,

Of naked human being-with spears in their hands, with bows, with shields, with wild glances and savages movements were powered into the clearing by the dark-faced and pensive forest [...] [3].

In his death too, Kurtz looks quite menacingly. His mouth looks "weirdly voracious" [3]. The fire of his eyes stoops Marlow very much and together sleepiness of his expression when Kurtz watches over his body, a wild a gorgeous looking woman comes to see Kurtz. She reads "the earth proudly, with a slight jingle and flash of barbarous ornaments" [3] we read in the text, (...) innumerable necklaces of glass beads on her neck; bizarre things, charms, gifts of which-men that hung about her, glittered and trembled at every step. She must have had the value of several elephant tusks upon her. 
She was savage and superb, wild-eyed and magnificent; there was something ominous and stately in her deliberate progress [3].

She is like Queen Jezebel wife of King Ahab, King of Israel; 22 years of governing has been done by him. More than any of his precursors, he sinned against Lord in heaven. He worshipped Baal. The Bible says,

He built a temple to Baal in Samaria, made an altar for him, and put it in the temple. He also put up an image of the goddess Asherah: He did more to arouse the anger of the LORD, the God of Israel, then all the Kings of Israel before him [1].

Just as the bewildering Jezebel is the right match to the King Ahab who is instrumental in provoking her husband to do all kinds of ugliness against God in Heaven, the formidable-looking strange woman that goes to visit Kurtz in his final movements is a right match to him. Quite obviously, it is this woman who is instrumental in provoking Kurtz her male partner to make him fiend-like.

Kurtz has "monstrous passions" [3] his over-ambitious soul goes beyond "the bounds of permitted aspiration" [3].This has pushed him into "incredible degradation" [3] he has killed himself "loose of the earth" [3]. He has "kicked the very earth to pieces" [3]. The text says "his soul was mad" [3] he is gone mad. His is an "inconceivable mystery of a soul that knew no restraint, no faith, and no fear, yet struggling blindly with itself" [3]. There is "a moment of abject terror in Kurtz as he approaches final moments" [3]. From his heart of darkness Kurtz's life, he is running fast, "ebbing, ebbing out of his heart into the sea of inexorable time" [3] on his death-bed, in the text shows, (...) My Intended, my station, my career, my ideas-these were the subjects for the occasional utterances of elevated sentiments. The shade of the original Kurtz frequented the bedside of the hollow

sham, whose fate it was to be buried presently in the mould of primaeval earth. But both the diabolic love and the unearthly hate of the mysteries it had penetrated fought for the possession of that soul satiated primitive emotions, avid of lying fame [3].

Kurtz cannot become a little child to enter into the kingdom of heaven so, as he is a man he wants a "kingdom of the earth" [5] Kurtz is not stable mentally and physically. He slowly succumbs to death on his boat. When he realises that he is going to die, he utters twice "The horror, the horror!" [3]. It is apparent that he might have seen a vision, reflecting on his life. He has set up black rituals worthy about the route and the tyrant. In his final movements, he looks like Dr.Faustus who has given his life to Lucifer for a riotous life of twenty-four years in exchange for his precious soul. When Lucifer and his companions visit Dr. Faustus at 12 O'clock in the night to take away his soul to hell, he screams aloud. Faustus in terrible despair calls for the mountains to fall upon him and requests the Earth to swallow him up. He looks upon heaven and pleads,

You start that reigned at my nativity Whose influence hath allotted death and hell Now draw up Faustus like a foggy mist Into the entrails of yon labouring cloud That when you vomit forth into the air My limbs may issue from your smoky mouths. So, that my soul may but ascend to heaven.
Both Kurtz and Dr. Faustus have the same DNA, and their hearts are overflowing with darkness. Nonetheless, both the characters have plenty of abominable traits in then, and they have been so fascinating to their companions and community.

\section{REFERENCES}

1. I Kings 11:5. Holy Bible. King James Version.

2. M. John, Paradise Lost. London: Oxford University Press, 1961

3. C. Joseph, Heart of Darkness. New Delhi: Prakash Books, India Pvt. Ltd, 2018.

4. G. Robert, "Soft Skills in Shakespeare's Antony and Cleopatra". Roots Volume 3 Special Issue 1 July 2017 ISSN: 2349-8684 (print article)

5. Friedrich, Nietzsche. Thus Spoke Zarathustra, London: Penguin Books. Transl. R.J. Hollingdale, 2003.

\section{AUTHORS PROFILE}

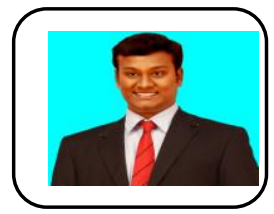

Dr. A. Hariharasudan has been working as Faculty of English in Kalasalingam Academy of Research and Education, Tamil Nadu, India. He completed his $\mathrm{PhD}$ in English. His research in $\mathrm{PhD}$ is postmodern readings of Indian Fiction. He is also serving as Language Editor to the reputed Scopus Indexed Journal - Polish Journal of Management Studies, Poland. He published numerous research articles related to English Language, Literature and Education 4.0 and also attended various international conferences, including Dubai and Bangkok. Now, his research interest is in Postmodernism, Digital English, Education 4.0 and Industry 4.0.

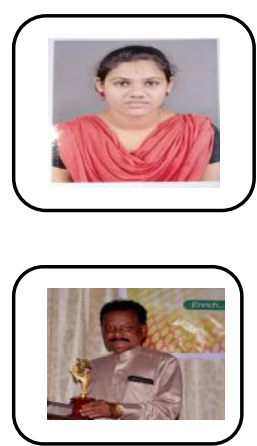

Ms. R.Juki Javla is a former Post Graduate Student o f Kalasalingam Academy of Research and Education. She completed M.A in English. Now, she is working as Assistant Professor of English in Thassim Beevi Abdul Kader College for women at Kilakarai. She is very much interested in teaching. This is her maiden attempt to pursue her $\mathrm{PhD}$. decades. He is a dedicated and inspiring English language teacher and researcher. Besides, he has authored two books and published 52 research papers in national and international journals.

Dr. S. Robert Gnanamony is a former Dean of School of Liberal Arts and Special Education, Kalasalingam Academy of Research and Education, Tamil Nadu, India. This was Dr. Robert's third spell of service. He has been in recognized collegiate 